5. Технологія косметичних засобів: підручник для студ. вищ. навч. закладів / О. Г. Башура [та ін.]; за ред. О. Г. Башури, О. І. Тихонова. Харків : НФаУ; Оригінал, 2017. 552 с.

6. Московченко О.Ю. Обоснование состава лечебно-профилактического средства для коррекции ксероза, вызванного возрастными изменениями кожи / О.Ю. Московченко, Т.Н. Ковалева. Сб. мат. научно-практ. конф. студ. и молодых ученых «Инновации в медицине и фармации». Минск, БГМУ, 2017. С. 665-668.

DOI https://doi.org/10.30525/978-9934-26-038-4-52

\title{
ВИВЧЕННЯ АНТИОКСИДАНТНОЇ ТА АНТИЦИТОЛІТИЧНОЇ АКТИВНОСТІ ЕКСТРАКТУ З ЛИСТЯ СЛИВИ ЗВИЧАЙНОЇ (PRUNUS DOMESTICA)
}

\author{
Кравченко В. М. \\ доктор біологічних наук, професор, \\ завідувачка кафедри біологічної хімії \\ Національний фармацевтичний університет
}

\begin{abstract}
Шовкова 3. В.
кандидат фармачевтичних наук,

доиент кафедри аналітичної хімії та аналітичної токсикології

Національний фармацевтичний університет
\end{abstract}

Сенюк I. В.

кандидат фармачевтичних наук,

дочент кафедри біологічної хімії

Національний фармащевтичний університет

\author{
Шовкова О. В. \\ кандидат фармацевтичних наук, \\ асистент кафедри біологічної хімії \\ Національний фармащевтичний університет \\ м. Харків, Украӥна
}

Однією $з$ актуальних проблем сучасної фармакологічної науки $є$ створення нових більш ефективних лікарських засобів для фармакокорекції захворювань гепатобіліарної системи. Ураження печінки $\epsilon$ широко розповсюдженою причиною захворюваності та смертності 
населення. Патології гепатобіліарної системи становлять глобальну проблему, що постає перед сучасною медициною [1, с. 2]. Перспективним напрямком вирішення зазначеної проблеми є використання рослинної сировини, яка у своїй хімічній складовій містить поліфенольні сполуки. Згідно даних літератури відомо, що поліфеноли виявляють широкий спектр біологічної активності та відіграють важливу роль у регуляції оксидативного балансу в організмі людини. Нашу увагу привернула слива звичайна (Prunus domestica L., род. Rosaceae), яка широко представлена на території України та достатньо відома своїми лікувальними властивостями і застосуванням у народній медицині [2, с. 7].

Вивчення антиоксидантних та антицитолітичних властивостей екстракту з листя сливи звичайної проводили на моделі гострого тетрахлорметанового ураження печінки, який викликали внутрішньошлунковим введенням щурам $50 \%$ олійного розчину тетрахлорметану у дозі 1 мл/100 г маси тіла [3, с. 24].

До фітохімічного складу екстракту з листя сливи звичайної містить відносно невелику концентрацію поліфенолів - до 12 \%. Тому для вивчення антиоксидантної активності було доцільно застосовувати досліджуваний екстракт у більш високих дозах. Для скринінгу антиоксидантної активності були обрані дози 25, 50, та 100 мг/кг, що відповідають 0,$05 ; 0,01$ та $0,05 \mathrm{LD}_{50}$. В якості препарату порівняння був використаний вітчизняний лікарський засіб, гепатопротектор - «Силібор», який застосовували у дозі 25 мг/кг (ЕД 30$)$ [3].

Розрахунок антиоксидантної активності проводили за рівнем ТБК активних продуктів (ТБК-АП) у тканині печінки [4, с. 132]. Вміст ТБКАП у гомогенаті печінки визначали колориметричним методом, який грунтується на здатності цієї суми сполук утворювати у кислому середовищі забарвлені триметинові комплекси з тіобарбітуровою кислотою, що мають максимум поглинання при 532 нм [5, с. 46]. Дослідні тварини були розділені на шість експериментальних груп: груп інтактного контролю (ІК); контрольна патологія (КП); тваринам третьої, четвертої та п'ятої груп на тлі тетрахлорметанового ураження печінки вводили досліджуваний екстракт у дозах 25, 50 та 100 мг/кг відповідно, тварини шостої групи отримували на тлі патології референс-препарат «Силібор» у дозі 25 мг/кг.

Результати досліджень наведені у табл. 1.

Аналіз експериментальних даних показав, що екстракт з листя сливи звичайної виявляв виразну антиоксидантну дію, пригнічуючи накопичення ТБК-АП на $32,46 \%$ у дозі 50 мг/кг та на $34,16 \%$ у дозі 100 мг/кг.

Найбільшу тенденцію щодо гальмування процесів перекисного окиснення ліпідів (ПОЛ) екстракт з листя сливи звичайної виявляв у дозі 25 мг/кг. Антиоксидантна активність складала 53,05 \%, що у 2,0 рази 
більше за активність препарату порівняння «Силібор». Так, «Силібор» у дозі 25 мг/кг суттєво не впливав на зниження вмісту ТБК-АП у тканині печінки за умов модельної патології, антиоксидантна активність складала 23,13\%.

Антицитолітичну активність розраховували за активністю ферменту аланінамінотрасферази (АлАТ) у сироватці крові дослідних тварин. Для визначення активності АлАТ використовували уніфікований динітрофенілгідразиновий метод, запропонований S. Reitman та S. Frenkel (1957) [6, с. 135].

У результаті експериментальних досліджень було встановлено, що екстракт 3 листя сливи звичайної у дозі 25 мг/кг не виявляв суттєвої антицитолітичної дії. Введення тваринам екстракту з листя сливи звичайної у дозі 25 мг/кг приводило до зниження активності АлАТ на $56,0 \%$ проти $60,7 \%$ у тварин, які отримували референт-препарат «Силібор» відносно показників групи КП.

Таблиця 1

Вплив екстракту з листя сливи звичайної на інтенсивність ПОЛ

та цитодеструктивних процесів за умов гострого токсичного гепатиту у порівнянні 3 «Силібором» $(\mathrm{n}=6)$

\begin{tabular}{|c|c|c|c|c|c|c|}
\hline \multirow{2}{*}{$\begin{array}{l}\text { Показ- } \\
\text { ник }\end{array}$} & \multirow{2}{*}{ IK } & \multirow{2}{*}{ КП } & \multicolumn{3}{|c|}{ Екстракт з листя сливи звичайної } & \multirow{2}{*}{$\begin{array}{l}\text { Силібор } \\
25 \text { мг/кг }\end{array}$} \\
\hline & & & 25 мг/кг & 50 мг/кг & $100 \mathrm{Mг} / \mathrm{Кг}$ & \\
\hline $\begin{array}{l}\text { ТБК- } \\
\text { АП } \\
\text { мкмоль/ } \\
\text { Г }\end{array}$ & $\begin{array}{l}30,77 \pm 0,9 \\
8\end{array}$ & $90,81 \pm 4,66$ & $\begin{array}{l}58,96 \pm \\
2,61\end{array}$ & $\begin{array}{l}70,30 \pm \\
4,97\end{array}$ & $\begin{array}{l}71,32 \pm \\
4,01\end{array}$ & $\begin{array}{l}76,92 \pm \\
1,31\end{array}$ \\
\hline $\begin{array}{l}\text { АлАТ } \\
\text { ммоль/л }\end{array}$ & $0,86 \pm 0,03$ & $2,36 \pm 0,1^{*}$ & $\begin{array}{l}1,52 \pm \\
0,06\end{array}$ & $1,75 \pm 0,02$ & $2,16 \pm 0,07$ & $1,45 \pm 0$ \\
\hline
\end{tabular}

Примітки:

- розбіжність достовірна по відношенню до IК ( $p \unlhd 0,05)$;

- розбіжність достовірна по відношенню до КП ( $p \unlhd 0,05)$;

- розбіжність достовірна по відношенню до референс-препарату “Силібор» $(p \unlhd 0,05)$;

n-кількість тварин у групі.

3 підвищенням дози антицитолітична дія екстракту з листя сливи звичайної знижувалася: у тварин, які отримували досліджуваний екстракт у дозі 50 мг/кг, активність АлАТ знижувалася на 40,7 \% у порівняні $з$ нелікованими тваринами (КП). У дозі 100 мг/кг екстракт з листя сливи звичайної виявляв антицитолітичний ефект, який становив $13,3 \%$. 
Той факт, що «Силібор» виявляв достатньо високу антицитолітичну активність на тлі помірного антиоксидантного ефекту, можливо, обумовлено здатністю його до гальмування розвитку цитолітичного синдрому за рахунок впливу не лише на перекисний, але й на фосфоліпазний механізм, про що свідчать дані наукової літератури щодо спроможності силімарину пригнічувати $\mathrm{Ca}^{2+}-$ залежну активацію фосфоліпаз, внаслідок гальмування трансмембранного переносу іонів кальцію [7, с. 12].

Таким чином, результати проведених експериментальних досліджень свідчать про наявність антицитолітичної та виразної антиоксидантної активності в екстракті, одержаного з листя сливи звичайної.

Аналіз експериментальних даних дозволив визначити фармакологічну ефективну дозу екстракту з листя сливи звичайної. Гепатопротекторна дія є багатокомпонентним видом фармакологічної активності, тому визначення ефективної дози проводили з урахуванням двох видів активності: антиоксидантної та антицитолітичної. На підставі отриманих даних встановлено, що за умов гострого тетрахлорметанового гепатиту досліджуваний екстракт у дозі 25 мг/кг виявляє виразні антиоксидантні властивості, перевищуючи активність препарату порівняння «Силібор» у 2,3 рази та не поступається останньому за антицитолітичною активністю.

Антиоксидантна та антицитолітична дія екстракту з листя сливи звичайної (Prunus domestica), ймовірно, пов'язана з наявністю в його хімічному складі поліфенольних сполук (хлорогенової, кавової, розмаринової, саліцилової кислот; кумаринів, флавонів та флавонолів.

\section{Література:}

1. Black C. J., Ford A. C. Global burden of irritable bowel syndrome: trends, predictions and risk factors. Nat Rev Gastroenterol Hepatol. 2020. № 17 (8). P. 473-486. doi: 10.1038/s41575-020-0286-8.

2. Determination of phenolic compounds, antioxidant capacity and organic acids contents of Prunus domestica L., Prunus cerasifera Ehrh. and Prunus spinosa L. fruits by HPLC / F. Celik et. al. Acta Chromatographica. 2017. № 29 (4). P. 507-510.

3. Дроговоз С. М., Сальникова С. И., Скакун Н. П., Слышков В. В. Методические рекомендации по экспериментальному изучению желчегонной, холеспазмолитической, холелитиазной и гепатопротекторной активности новых лекарственных средств // Издание оффициальное. Киев: ФК МЗ Украины, 1994.

4. Стальная И. Д., Гаришвили Т. Г. Метод определения диеновой конъюгации ненасыщенных высших жирных кислот. Современные 
методы в биохимии / под ред. В. Н. Ореховича. М. : Медицина, 1977. C. $63-64$.

5. Спекторофотометрическое определение продуктов перекисного окисления липидов / под ред. проф. А. И. Карпищенко. Медицинская лабораторная диагностика (программы и алгоритмы). СПб. : «Интермедика», 1997. С. 48-52.

6. Камышников В. С. Справочник по клинико-биохимической лабораторной диагностики. Мн. : Беларусь, 2002. Т. 1. 495 с.

7. Silibor effects on cytolysis in the rat liver under $\mathrm{CCL}_{4}$ intoxication / D. Uzbekova et al. Journal of Hepatology. 2002. № 36. P. 152.

DOI https://doi.org/10.30525/978-9934-26-038-4-53

\title{
АНАЛІЗ ЗАКОНОДАВЧИХ ІНІЦИАТИВ У КОСМЕТИЧНІЙ ГАЛУЗІ УКРАЇНИ НА СУЧАСНОМУ ЕТАПІ
}

\author{
Лебединець В. О. \\ доктор фармачевтичних наук, професор, \\ професор кафедри управління, \\ економіки та забезпечення якості у фармаціі \\ Національний фармацевтичний університет \\ Казакова I. C. \\ аспірант кафедри управління, \\ економіки та забезпечення якості у фармачії \\ Національний фармацевтичний університет

\section{Казакова В. C.} \\ кандидат фармацевтичних наук, доиент, \\ дочент кафедри косметології і аромології \\ Національний фармацевтичний університет \\ м. Харків, Украӥна
}

Косметична галузь Україні на сучасному етапі знаходиться на стадії реформування. Законодавчі ініціативи у косметичній сфері направлені на виконання вимог європейських стандартів, необхідність відповідності яким визначена принципами євроінтеграції України згідно Угоди про Асоціацію між Україною та Європейським Союзом (СС) [1].

Метою дослідження був аналіз законодавчих ініціатив у косметичній галузі України та надання рекомендацій щодо ефективного впрова- 